\title{
IMPACT OF DRIVING TECHNIQUES ON FUEL CONSUMPTION
}

Climatologists constantly point to the change of the climate on Earth. They consider CO2 emissions to be one of the main causes of these changes. Transport is significant producer of the greenhouse gases. If one litre of gasoline is burnt, $2.5 \mathrm{~kg}$ of CO2 is released into environment. Incineration of one litre of oil means that the air gets $2.7 \mathrm{~kg}$ of CO2 [1]. Moreover, the air gets other pollutants, particularly nitrogen oxides NOx, unburned hydrocarbons, particulates. If we want to stop or delay the climate change, we should minimize production of the greenhouse gases. This objective could be implemented through legislation, designing of more efficient propulsion units, construction of infrastructure or using of alternative fuels. The easiest way is to minimize vehicle fuel consumption. This is dependent on driver and his driving techniques. The technical condition of the vehicle, route selection and the type of the vehicle are also significant [2]. We want to show the influence of the driving technique on the fuel consumption. Article describes four different driving techniques and their impact on the fuel consumption.

Keywords: Transport, greenhouse gases, vehicle fuel consumption, driving techniques, change of the climate.

\section{Conditions for experiment}

We compared the impact of a driving technique on the vehicle consumption by driving on the street circuit. To minimize the impact of inequalities and random effects on vehicle consumption we carried out two measurements for each driving technique. The third measurement was performed when the results between the first two measurements were significantly different. Traffic density has a significant effect on the car consumption. To eliminate this impact on measurements, we performed the measurements out in the evening with a minimum traffic density. When the waiting time at the traffic lights or junction was 1 minute or more, we annulled the measurement and started a new one [3].

Before measuring the consumption, the vehicle was warmed up to the operating temperature by driving to at least $10 \mathrm{~km}$ distance. The vehicle was operated by the same driver during the consumption measuring and the driver was following traffic rules and regulations valid in Slovakia. The measurements were carried out on Suzuki SX 4 with front-wheel drive. The technical characteristics of the vehicle are described in Table 1.

\section{Description of the measuring circuit}

Measurements were done on the circuit in the city of Zilina. The starting point of the circuit number 1 is at an altitude of $363 \mathrm{~m}$. The highest point of the route is at an altitude of 401

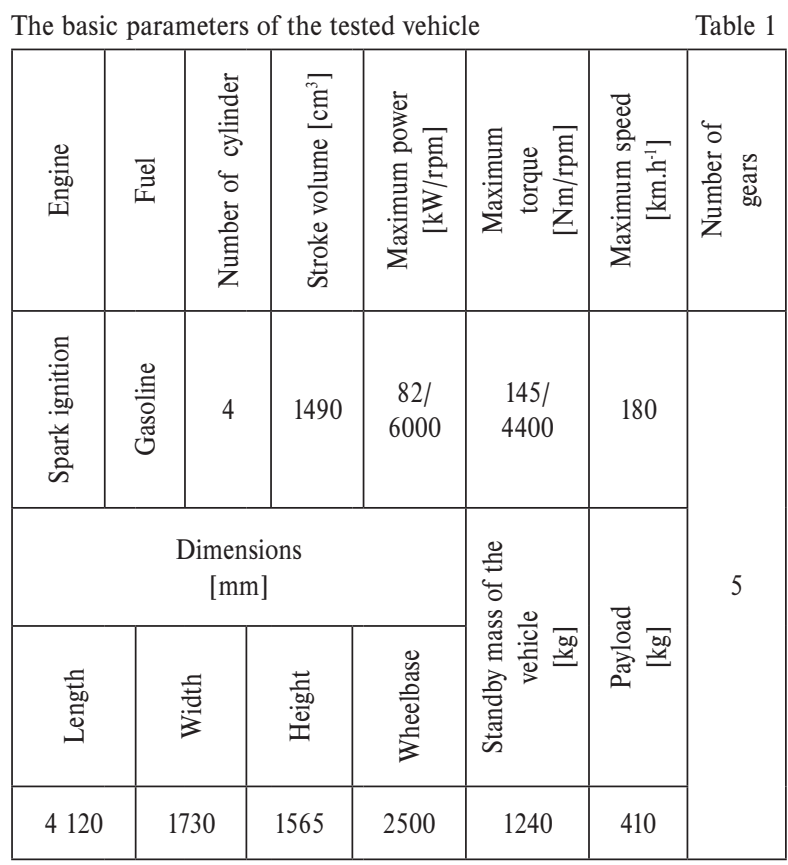

Source: vehicle manufacturer

meters and the lowest point is at an altitude of 351 metres. Altitude values were determined by the Google earth program. Altitude profile of the measuring circuit is shown in Fig. 1 [4].

\footnotetext{
* ${ }^{1}$ Vladimír Rievaj, ${ }^{1}$ Lenka Mokrickova, ${ }^{2}$ Juraj Rievaj

${ }^{1}$ Department of Road and Urban Transport, Faculty of Operation and Economics of Transport and Communications, University of Zilina, Slovakia

${ }^{2}$ Headington Close, Cambridge Cambridgeshire, United Kingdom

E-mail: vladimir.rievaj@fpedas.uniza.sk
} 


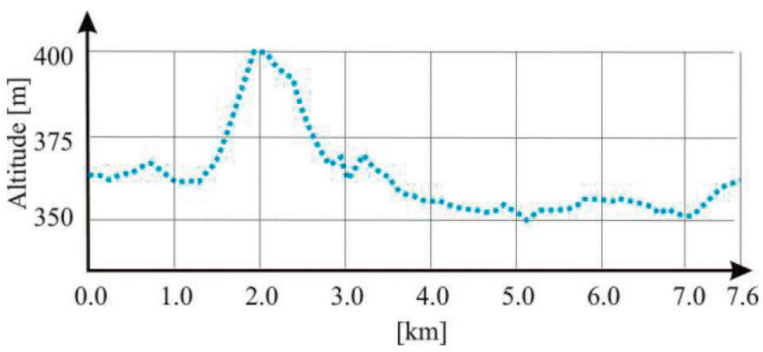

Fig. 1 Elevation profile of the measuring circle

The route was divided into sections depending on the longitudinal slope, the speed limit or obligation to give way to other vehicles.

The first section, $100 \mathrm{~m}$ long, was used to achieve a speed of $50 \mathrm{~km} / \mathrm{h}$. The driver drove through the second section at a speed of $50 \mathrm{~km} / \mathrm{h}$ and he was obliged to slow down to $40 \mathrm{~km} / \mathrm{h}$ at the end of the section. The driver kept driving at a speed of $40 \mathrm{~km} / \mathrm{h}$ on the third section. The driver accelerated to $50 \mathrm{~km} / \mathrm{h}$ in the fourth section and at the end of it he slowed down to a speed of $40 \mathrm{~km} / \mathrm{h}$. Here is an intersection where the driver turned to the right into the fifth section. The average slope of this section is $5 \%$. The driver sped up to $50 \mathrm{~km} / \mathrm{h}$ in this section. The driver slowed down to a speed of $40 \mathrm{~km} / \mathrm{h}$ at the end of this section. The sixth section had degressive character and the driver braked by engine. He had to slow down to a speed of $30 \mathrm{~km} / \mathrm{h}$ at the end of the section because he was obliged to give way to the vehicles traveling on the main road. The vehicle increased its speed again to $50 \mathrm{~km} / \mathrm{h}$ on the seventh section and went through a slight incline. The eighth section of the road had a decline and at the end of it the driver entered a roundabout and had to slow down to $30 \mathrm{~km} / \mathrm{h}$. The driver could go through the ninth section at a speed of $50 \mathrm{~km} / \mathrm{h}$ but at the end of it he had to slow down to $30 \mathrm{~km} / \mathrm{h}$ as he entered a roundabout again. The tenth section had a decline. At the end of this section, the driver was turning to the left so he had to give way to the vehicles coming from the opposite side. The driver slowed down to $30 \mathrm{~km} / \mathrm{h}$ and entered the eleventh section. This sector had an incline and the driver could increase the speed to $70 \mathrm{~km} / \mathrm{h}$. He increased the speed to this speed limit. There is a road sign STOP - GIVE WAY at the end of the eleventh section so the driver had to stop the vehicle. The beginning of the twelfth section had a speed limit of $50 \mathrm{~km} / \mathrm{h}$ so the vehicle accelerated to $50 \mathrm{~km} / \mathrm{h}$. Then the driver had to slow down to $40 \mathrm{~km} / \mathrm{h}$ due to the speed limit at the end of this section. At the thirteenth section, the driver went through the first $100 \mathrm{~m}$ at a speed of $40 \mathrm{~km} / \mathrm{h}$, after that he accelerated to $50 \mathrm{~km} / \mathrm{h}$ which was also the speed limit. The road had a slight decline. The driver had to slow down to 30 $\mathrm{km} / \mathrm{h}$ at the end of the section as he entered a roundabout. The fourteenth section had a moderate incline. The speed limit was $50 \mathrm{~km} / \mathrm{h}$. At the end, the driver parked the vehicle at the spot where we started the measurements [5] and [6].

\section{Driving technique description}

The aim was to investigate the effects of driving techniques on the car consumption and, therefore, measurements were taken for different driving techniques. This route was selected so that the driver had to change the speed of the vehicle frequently and there were only short segments of the road where the driver could drive at a constant speed. The measurement was carried out for four different driving modes, which are described below.

A The vehicle engine was warmed up to the operating temperature. The driver tried to keep the vehicle engine at low revs, used deceleration of the vehicle and engine braking. The driver used only the first four gears.

B The engine of the vehicle was warmed up to the operating temperature. The driver tried to keep the vehicle at a low speed and turned on the cruise control when driving at the constant speed. He used only the first four gears.

C The engine of the vehicle was warmed up to the operating temperature. The ride was dynamic and the driver kept the vehicle at higher speeds. He used only the first three gears.

D The driver tried to drive the vehicle economically as described in section A. The only difference was that he started to drive as soon as he turned the engine on - the cold start [7] and [8].

The measurement results are in Table 2 .

The results of the measurements

Table 2

\begin{tabular}{|c|c|c|c|c|c|}
\hline \multirow[t]{2}{*}{ 芯 } & \multirow[t]{2}{*}{ 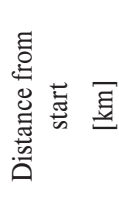 } & \multicolumn{4}{|c|}{$\begin{array}{c}\text { Average fuel consumption of the vehicle } \\
\text { from the start, depending on driving } \\
\text { techniques of driver } \\
{[1 / 100 \mathrm{~km}]}\end{array}$} \\
\hline & & A & B & $\mathrm{C}$ & D \\
\hline 1 & 0.1 & 16.2 & 15.1 & 17.9 & 27.6 \\
\hline 2 & 0.6 & 6.5 & 6.5 & 7.4 & 8.1 \\
\hline 3 & 0.9 & 5.5 & 5.5 & 6.5 & 6.2 \\
\hline 4 & 1.2 & 5.1 & 5.0 & 5.9 & 6.0 \\
\hline 5 & 2.0 & 6.7 & 6.6 & 7.4 & 7.5 \\
\hline 6 & 3.0 & 5.2 & 5.1 & 5.5 & 5.6 \\
\hline 7 & 3.5 & 5.4 & 5.2 & 5.5 & 5.7 \\
\hline 8 & 4.2 & 4.8 & 4.8 & 5.3 & 5.4 \\
\hline 9 & 4.4 & 4.8 & 4.7 & 5.4 & 5.2 \\
\hline 10 & 4.9 & 4.8 & 4.6 & 5.4 & 5.2 \\
\hline 11 & 5.6 & 4.8 & 4.7 & 5.3 & 5.2 \\
\hline 12 & 6.1 & 4.9 & 4.8 & 5.4 & 5.4 \\
\hline 13 & 6.6 & 4.8 & 4.7 & 5.3 & 5.3 \\
\hline 14 & 7.6 & 4.9 & 4.7 & 5.3 & 5.3 \\
\hline
\end{tabular}




\section{Discussion of results}

The results show that the lowest average fuel consumption was achieved when using the cruise control. Using this driving technique, the driver saved 0.2 litres of fuel per $100 \mathrm{~km}$. The cruise control affects not only fuel consumption but it also contributes to road safety. While using the cruise control the driver doesn't have to watch the speedometer to make sure he doesn't exceed speed limit. This will enable him to give more attention to the other cars and to what is happening on the road and, therefore, to drive more carefully. Cruise control is automatically deactivated when the vehicle brakes, so there is no damage risk for the engine. However, it is necessary to be careful when changing the speed gears, because some cruise controls are unable to react to this and so the engine speed is increased unreasonably. If we compare the fuel consumption of driving at higher speeds and using only the $1^{\text {st }}, 2^{\text {nd }}$ and $3^{\text {rd }}$ gear to the economical driving, the consumption increased by 0.4 litres $/ 100 \mathrm{~km}$. When we compare it to the driving with the cruise control, the difference is 0.6 litres / 100km. The driver increased the dynamic potential of the vehicle but it was totally unnecessary. In addition to increased consumption, higher engine speed also means increased noise of the vehicle.

To measure differences in consumption we also looked at the driving with cold engine. The overall average fuel consumption of the vehicle was similar to the situation when the driver kept the engine at higher speeds by using only the $1^{\text {st }}, 2^{\text {nd }}$ and $3^{\text {rd }}$ gear. In this case very significant is the increased average fuel consumption of the vehicle in the first three kilometres. After accomplishing this distance the vehicle engine was warmed up to the operating temperature and started to work economically.

The manufacturer of tested vehicle determines that fuel consumption is 7.8 litres / $100 \mathrm{~km}$ in urban mode.

\section{References}

\section{Conclusions}

Our measurements proved that the driver can significantly influence the consumption of his car by using different driving techniques.

If we compare the economical driving technique to the driving with the cruise control, the vehicle consumption was 0.2 litres / $100 \mathrm{~km}$ higher and it means increase by $4.3 \%$.

In the case of dynamic driving the vehicle consumption was 0.6 litres / 100km higher. It means an increase by $12.8 \%$.

Cold start driving is a different case. The vehicle showed significantly higher fuel consumption on the first sections. This fact is even more serious because the catalyst vehicle begins to work with a time lag and the exhaust system emits unregulated emissions into the environment. Driving on short distance brings increased fuel consumption, but it also leads to increased production of emissions.

\section{Acknowledgement}

This contribution/publication is the result of the project implementation:

Centre of Excellence for Systems and Services of Intelligent Transport II, ITMS 26220120050 supported by the Research \& Development Operational Programme funded by the ERDF.

Podporujeme vyskumne aktivity na Slovensku/Projekt je spolufinancovany zo zdrojov EU.

Agentúra Ministerstva školstva, vedy, viskumu a športu SR pre štrukturálne fondy EÚ

VEGA Projekt c. 1/0331/2014 - SULGAN, M. a kol.: The modelling of distribution logistics system could lead to solving problem of distribution of the existing or new projecting of distribution logistics system in company, University of Zilina, FPEDAS, 2014-2016.

[1] RIEVAJ, V., MAJEROVA, Z.: How to Reduce Emissions Originated in Road Transport?, Machines, Technologies, Materials, [intern. virtual j], vol. 7, No. 6, 2013, pp. 24-27, http://mech-ing.com/journal/6-2013.html, ISSN 1313-0226.

[2] SKRUCANY, S. et. al.: Elements of body fuel-saving cars (in Slovak),

Voda co nas drzi nad vodou, [virtual j.], Zilina : University of Zilina, 2015, pp. 153-162, ISBN 978-80-5541156-9.

[3] SARKAN, B., HOLESA, L., CABAN, J.: Measurement of Fuel Consumption of a Road Motor Vehicle by Outdoor Driving Resting, Postepy nauki i techniki = Advances in Science and Technology, vol. 7, No. 19, 2013, pp. 70-74., ISSN 2080-4075.

[4] SARKAN, B., VRABEL, J.: Safety and Ecology of Road Vehicle Operation, [virtual j.], $1^{\text {st }}$ ed., Bytca: Druska Books as university textbook, 2014, CD-ROM, ISBN 978-80-89646-92-0.

[5] SKRUCANY, T., SARKAN, B., GNAP, J.: Aerodynamic Trailer Devices and Drag Reduction Examined in Wind Tunnel (in Slovak), proc. of $12^{\text {th }}$ intern. conference New Trends in Statics and Dynamics of Buildings, October, 2014, Bratislava: Slovak University of Technology, ISBN 978-80-227-4259-7, CD-ROM, 8 p. 
[6] SARKAN, B., SIMKOVA, I.: Laboratory Measurement of Fuel Consumption Passenger Vehicles (in Slovak), proc. of intern. Scientific conference MOSATT 2013: Modern Safety Technologies in Transportation, September, 2013, Zlata Idka : Kosice : Perpetis, ISBN 978-80-971432-0-6, pp. 232-236.

[7] SARKAN, B., SKRUCANY, T., MAJEROVA, Z.: Possibilities of Measuring the Brake Specific Fuel Consumption in Road Vehicle Operation (in Slovak), Machines, Technologies, Materials, vol. 8, No. 5, 2014, [intern. virtual j.], ISSN 1313-0226, online, pp. 19-21.

[8] KENDRA, M. et al.: Energy Consumption and GHG Production in Railway and Road Passenger Regional Transport, Intern. J. of Chemical, Nuclear, Metallurgical and Materials Engineering, vol. 9, No. 11, 2015, pp. 3473-3476, online: http://waset.org/ publications/10002884/energy-consumption-and-ghg-production-in-railway-and-road-passenger-regional-transport, ISSN 1307-6892. 